BioLink : Jurnal Biologi Lingkungan, Industri dan Kesehatan, Vol. 6 (1) Agustus (2019)

ISSN: 2356- 458X (print) ISSN: 2550-1305 (online)

BioLink

Jurnal Biologi Lingkungan, Industri, Kesehatan

Available online http://ojs.uma.ac.id/index.php/biolink

\title{
UJI EFEKTIVITAS ANTIBAKTERI EKSTRAK DAUN SIRSAK (ANNONA MURICATA LINN.) TERHADAP BAKTERI PROPIONIBACTERIUM ACNES
}

\section{EFFECTIVENESS TEST OF SOURSOP LEAVES (ANNONA MURICATA LINN) EXTRACT AS ANTIBACTERIAL FOR PROPIONIBACTERIUM ACNES}

\section{Yurlina Zai, Agnes Yohana Kristino, Sri Lestari Ramadhani Nasution, Oliviti Natali*}

\author{
Program Studi Pendidikan Dokter, Fakultas Kedokteran, Universitas Prima Indonesia, \\ Indonesia
}

Diterima : 08-02-19; Disetujui : 29-04-19: Diterbitkan : 12-08-19

*Corresponding author: E-mail: *olievitie@gmail.com

\begin{abstract}
Abstrak
Penelitian ini bertujuan untuk mengetahui efektivitas antibakteri ekstrak daun sirsak (Annona muricata L.). Metode yang digunakan adalah metode difusi agar. Daun diekstraksi dengan metode maserasi, dengan menggunakan etanol sebagai pelarut. Ekstrak daun sirsak yang diperoleh kemudian diencerkan dengan menggunakan etanol $96 \%$ pada konsentrasi $20 \%, 40 \%, 60 \%$, 80\%. Kontrol positif menggunakan klindamisin dan kontrol negatif menggunakan aquades steril. Model penelitian yang digunakan dalam penetian ini adalah model penelitian eksperimental secara In Vitro. Hasil penelitian menunjukkan bahwa ekstrak daun sirsak memiliki efektivitas anti bakteri terhadap Propionibacterium acnes dengan rata-rata diameter zona hambat 9,7 mm;13,7 mm;15,7 mm;16,3 mm; kontrol positif (klindamisin) 21,0 mm ; dan kontrol negatif (akuadest) tidak memiliki nilai untuk dapat menghambat pertumbuhan bakteri.
\end{abstract}

Kata Kunci: Annona muricata Linn, ekstrak, antibakteri, Propionibacterium acnes

\begin{abstract}
This research aims to determine the effectiveness of the antibacterial soursop leaf extract (Annona muricata L.). The method used is the agar diffusion method. The leaves were extracted by maceration method, using ethanol as a solvent. The soursop leaf extract obtained was then diluted using ethanol $96 \%$ at a concentration of $20 \%, 40 \%, 60 \%, 80 \%$. Positive control using clindamycin and negative controls using sterile aquadest. The research model used in this study is an experimental research model In Vitro of type. The results showed that soursop leaf extract had antibacterial effectiveness against Propionibacterium acnes with an average inhibition zone diameter of 9,7 mm;13,7 mm;15,7 mm;16,3 $\mathrm{mm}$; positive control (clindamysin) 21,0 mm; and negative control (aquadest) have no value tobe able to inhibit bacterial growth.
\end{abstract}

Key Words: Annona muricata Linn, extact, antibacterial, Propionibacterium acnes

How to Cite: Zai, Y., Kristino, A.Y., Nasution, Sri., L.R., dan Natali, O., (2019). Uji Efektivitas Antibakteri Ekstrak Daun Sirsak ( Annona muricata L.) Terhadap Bakteri Proprionibacterium acnes, BioLink: Jurnal Biologi Lingkungan, Industri dan Kesehatan, Vol.6 (1): Hal. 59-64 
Zai, Y., Kristino, A.Y., Nasution, Sri., L.R., dan Natali, O. Uji Efektivitas Antibakteri Ekstrak Daun Sirsak ( Annona muricata L.) Terhadap Bakteri Proprionibacterium acnes.

\section{PENDAHULUAN}

Salah satu penyakit kulit yang sering menjadi keresahan bagi para remaja dan dewasa muda yaitu jerawat atau dalam bahasa medisnya akne vulgaris. Salah satu penyakit kulit yang selalu mendapat perhatian bagi para remaja dan dewasa muda adalah jerawat atau dalam bahasa medisnya acne vulgaris (Manarisip, Kepel and Rompas, 2015).

Akne vulgaris merupakan penyakit kulit yang terjadi akibat peradangan menahun folikel polisebasea yang ditandai dengan adanya komedo, papul, pustul, nodul pada tempat predileksinya yaitu pada muka, bahu, dada bagian atas, lengan atas dan punggung bagian atas (Adhi et al., 2018).

Prevalensi tertinggi timbulnya jerawat yaitu pada umur 16-17 tahun, dimana pada wanita berkisar $83-85 \%$ dan pada pria berkisar 95-100\%. Beberapa faktor penyebab jerawat diantaranya faktor genetik, ras, musim, psikis, hormonal atau adanya infeksi bakteri, namun pada umumnya penyebab timbulnya jerawat disebabkan oleh infeksi bakteri. Salah satu bakteri penyebab jerawat adalah bakteri Propionibacterium acnes. (P. acne) (Latifah and Kurniawaty, 2015).

P. acnes termasuk bakteri flora normal pada kulit yang merupakan bakteri gram positif, pleomorfik, dan bersifat anaerob aerotoleran. Bakteri ini berperan dalam pembentukan jerawat, dengan menghasilkan lipase yang memecah asam lemak bebas dari lipid kulit sehingga menyebabkan peradangan. Peradangan tersebut menyebabkan bakteri ini berproliferasi dan memperparah lesi inflamasi dengan merangsang produksi sitokin proinflamasi(Fauzi, 2014).

Pengobatan akne vulgaris hingga saat ini masih dikembangkan karena meningkatnya resistensi antibiotik terhadap P.acnes. Salah satu antibiotik yang digunakan untuk upaya untuk mengobati jerawat adalah seperti ampisilin, eritromisin, atau klindamisin dan tetrasiklin. Karena itu butuh alternatif lain dalam mengobati akne vulgaris dari bahan alami yang diharapkan bisa meminimalkan efek samping dari penggunaan obat antibiotik yang tidak diinginkan.(Restiana, Khotimah and Fitrianingrum, 2016).

Tumbuhan merupakan salah satu kekayaan sumber daya alam hayati di Indonesia yang didalamnya terkandung berbagai macam zat kimia aktif yang memiliki potensi besar untuk digunakan manusia dalam bidang pengobatan, salah satunya dapat bersifat sebagai antibakteri (Fauzi, 2014). Salah satu tanaman yang dapat berfungsi sebagai anti bakteri adalah ekstrak daun sirsak (Carbajal 1991). et al., 2014). 
Annona muricata L, dikenal sebagai sirsak di Indonesia, ditemukan dari Amerika Tengah ke Amerika Selatan, termasuk Amerika Utara, Amerika Timur Laut dan daerah Tenggara Brazil.(Rusmiyati, Husain and Alam, 2012)

Daun sirsak (Annona muricata L.) oleh masyarakat dimanfaatkan sebagai anti bakteri, anti virus, anti oksidan dan anti jamur, anti parasit dan anti hipertensi ((Carbajal 1991). et al., 2014) Kandungan senyawa dalam daun sirsak antara lain steroid/terpenoid, flavonoid, alkaloid, dan tannin. (Febriani, Mulyanti and Rismawati, 2015).

Tujuan penelitian ini adalah melakukan uji efektivitas antibakteri ekstrak daun sirsak (Annona muricata L.) terhadap pertumbuhan bakteri P. Acne. Sehingga bermanfaat sebagai alternatif pengobatan herbal pada infeksi P. acne.

\section{METODE PENELITIAN}

\section{Jenis dan rancangan penelitian}

Penelitian ini menggunakan penelitian eksperimen laboratorik dengan menggunakan difusi cakram untuk melihat efektivitas antibakteri ekstrak daun Sirsak (Annona muricata L.) terhadap bakteri Propionibacterium acnes.

\section{Alat dan bahan}

Alat-alat yang digunakan pada penelitian ini meliputi kamera, toples kaca, kertas saring, gelas ukur, beaker glass, tabung reaksi, rak tabung reaksi, cawan petri, penjepit tabung, pipet tetes, spatula, jangka sorong, jarum ose, kapas, mesin rotary evaporator, waterbath, autoclave, inkubator, lemari pendingin, blender, pinset, hotplate, pipet tetes, timbangan digital, jangka sorong, cotton swab, laminar air flow, korek api, kain.

Bahan yang digunakan pada penelitian ini adalah daun sirsak (Annona muricata L.), akuades, Muller Hilton Agar (MHA), Nutrient Broth (NB), lampu spiritus, etanol 90\%, masker, handscoon, kertas whatman, kapas, spiritus, alkohol 70\%, yang diperoleh bakteri P. acnes dari Laboratorium Mikrobiologi Universitas Sumatera Utara.

\section{Tahapan Penelitian}

a. Persiapan Sampel

Daun sirsak yang baru diperoleh dari pasar dipisahkan terlebih dahulu dari batang dan disisihkan. Kemudian, bersihkan dari kotoran seperti debu yang dicuci dengan air bersih yang mengalir. Kemudian, dikeringkan dengan cara disebar diatas aluminium foil atau diatas koran dan ditimbang beratnya. Simplisia di blender menjadi serbuk dan disimpan dalam toples kaca yang diberi stiker label lalu disimpan pada tempat yang terhindari dari cahaya matahari. 
Zai, Y., Kristino, A.Y., Nasution, Sri., L.R., dan Natali, O. Uji Efektivitas Antibakteri Ekstrak Daun Sirsak ( Annona muricata L.) Terhadap Bakteri Proprionibacterium acnes.

b. Uji Efektivitas Antibakteri

1. Pembuatan Larutan Uji Ekstrak Daun Sirsak dengan Berbagai Konsentrasi

Ekstrak metanol dimasukkan ke dalam tabung pengencer masing-masing 0.2 gram, 0.4 gram, 0.6 gram dan 0.8 gram yang selanjutnya ditambahkan dengan larutan etanol 96\% 10ml. Dari hasil pengenceran tersebut diperoleh konsentrasi ekstrak daun sirsak (Annona muricata L.) masing-masing 20\%, 40\%, $60 \%$ dan 80\%. Selanjutnya keenam konsentrasi dalam masing-masing tabung tersebut dihomogenkan. Setelah homogen, ke dalam masing masing tabung tersebut direndam kertas whatman yang akan dimasukkan kedalam cawan petri berisi MHA.

2. Pengujian Efektivitas antibakterial Ekstrak Daun Sirsak (Annona muricata L.) Terhadap Propionibacterium acne MHA dituang ke dalam cawan petri steril, lalu tunggu dingin sampai agar

Tabel 1. Data hasil uji efektivitas ekstraik daun sirsak (Annona muricata L.) Propionibacterium Acnes mengeras. Kemudian, disiapkan cotton swab yang steril lalu dicelupkan ke dalam tabungan yang berisi bakteri atau ke dalam inokulum bakteri. Swab bakteri diatas permukaan agar hingga rata. Kemudian, letakkan cakram kertas yang telah direndam pada setiap konsentrasi didalam petri yang telah diswab kemudian diinkubasi pada inkubator suhu $37^{\circ} \mathrm{C}$ selama \pm 48 jam, kemudian cek hasil. Setelah 48 jam periksa dan ukur zona hambat atau zona bening yang terbentuk menggunakan jangka sorong. Data hasil uji aktivitas antibakteri kemudian dianalisis secara statistik menggunakan metode grafik.

\section{HASIL DAN PEMBAHASAN}

Hasil pengukuran diameter daerah hambat ekstrak daun sirsak (Annona muricata L.) dapat dilihat pada Tabel 1.1.

\begin{tabular}{ccccc}
\hline Perlakuan & \multicolumn{4}{c}{ Diameter Zona Hambat (mm) } \\
\hline \multirow{2}{*}{ Perlakuan } & \multicolumn{3}{c}{ Propionibacterium acne } & $\begin{array}{c}\text { Rata-rata Diameter Zona } \\
\text { Hambat (mm) }\end{array}$ \\
\cline { 2 - 4 } & I & II & III & 16,3 \\
\hline $80 \%$ & 17 & 17 & 16 & 15,7 \\
\hline $60 \%$ & 16 & 16 & 15 & 13,7 \\
\hline $40 \%$ & 14 & 14 & 13 & 9,7 \\
\hline $20 \%$ & 10 & 10 & 9 & 21,0 \\
\hline K $(+)$ & & 21 & & 0 \\
\hline K $(-)$ & & 0 & & \\
\hline
\end{tabular}




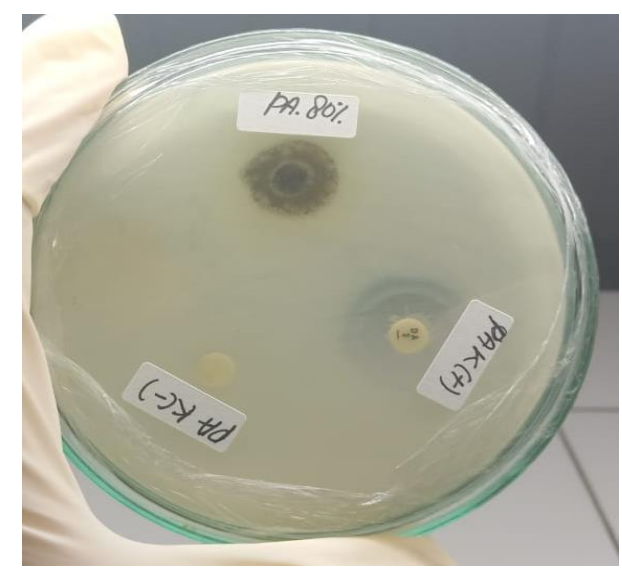

Gambar 1. Zona hambat yang terbentuk pada media MHA

Berdasarkan table 1. zona hambat ekstrak daun sirsak juga memiliki daya yang terbentuk disekitar kertas saring hambat terhadap pertumbuhan bakteri yang berisi ekstrak daun sirsak Propionibacterium acnes. konsentrasi $80 \%$ memiliki daya hambat rata-rata $16,3 \mathrm{~mm}$, konsentrasi $60 \%$ memiliki daya hambat rata-rata $15,7 \mathrm{~mm}$, konsentrasi $40 \%$ memiliki daya hambat rata-rata $13,7 \mathrm{~mm}$, konsentrasi $20 \%$ memiliki daya hambat rata-rata $9,7 \mathrm{~mm}$. Zona hambat yang terbentuk pada antibiotik clindamycin lebih kuat dibandingan dengan rata-rata zona hambat yang terbentuk pada ekstrak daun sirsak dengan rata-rata diameter zona hambat sebesar $21 \mathrm{~mm}$, sedangkan pada akuades tidak terbentuk zona hambat, yang berarti akuades sebagai control negatif tidak dapat menghambat pertumbuhan bakteri Propionibacterium acnes. Tetapi dari selisih antara diameter zona hambat membuktikan bahwa efek antibakteri clindamycin masih lebih besar dibandingkan dengan antibakteri yang ada pada ekstrak daun sirsak tetapi dengan penelitian ini juga membuktikan bahwa

Berdasarkan hasil pengamatan dari 3 kali perlakuan dengan menggunankan kertas saring yang direndam didalam ekstrak daun sirsak semua menunjukkan adanya daya hambat terhadap pertumbuhan Propionibacterium acnes. Hal ini karena adanya senyawa antibakteri dalam ekstrak daun sirsak yang diperoleh dari kandungan kimia yang terdapat di dalamnya, seperti tannin, alkaloid, saponin dan flavonoid yang mampu menghambat pertumbuhan dari bakteri Propionibacterium acnes.

Hasil penelitian ini juga didukung dengan penelitian sebelumnya tentang Bioaktivitas Ekstrak Metanol Daun Muda Sirsak Annona muricata L. Sebagai Antibakteri Terhadap Staphylococcus aureus dan Propionibacterium acnes. Hasil yang diperoleh terbukti ekstrak daun muda sirsak dapat menghambat 
Zai, Y., Kristino, A.Y., Nasution, Sri., L.R., dan Natali, O. Uji Efektivitas Antibakteri Ekstrak Daun Sirsak ( Annona muricata L.) Terhadap Bakteri Proprionibacterium acnes.

pertumbuhan koloni Propionibacterium

acnes.

\section{SIMPULAN}

Berdasarkan hasil penelitian dapat disimpulkan bahwa ekstrak daun sirsak (Annona muricata L.) memiliki efektivitas terhadap pertumbuhan Propionibacterium acnes pada konsentrasi $80 \%, 60 \%, 40 \%$, dan $20 \%$.

\section{UCAPAN TERIMA KASIH}

Penulis mengucapkan terimakasih kepada Oliviti Natali selaku dosen pembimbing yang sudah membantu mengarahkan selama penelitian.

\section{DAFTAR PUSTAKA}

(Carbajal 1991). et al. (2014) 'Uji Efek Penurunan Tekanan Darah Ekstrak Etanol Daun Sirsak ( Annona muricata L .) pada Tikus Wistar Jantan', XXXIX(1), pp. 40-44.

Adhi, D. et al. (2018) Ilmu Penyakit Kulit Dan Kelamin, Fkui.
Davis, W. W. and Stout, T. R. (1971) 'Disc Plate Method of Microbiological Antibiotic Assay', National Center for Biotechnology Information.

Fauzi, et al (2014) 'Uji Aktivitas Antibakteri Ekstrak Etanol dan Fraksi Daun Jawer Kotok (Coleus atropurpureus (L) Benth.) Terhadap Bakteri Propionibacterium acnes ATTC 1223 dan Staphylococcus epidermidis ATTC 12228', Farmaka.

Febriani, D., Mulyanti, D. and Rismawati, E. (2015) 'Karakterisasi Simplisia dan Ekstrak Etanol Daun Sirsak (', pp. 475-48o.

Latifah, S. and Kurniawaty, E. (2015) 'Stres dengan Akne Vulgaris', Jurnal Kedokteran Unila, 4(9), pp. 129-134.

Manarisip, C. K., Kepel, B. J. and Rompas, S. S. (2015) 'Hubungan Stres Dengan Kejadian Acne Vulgaris Pada Mahasiswa Semester V (Lima) Program Studi Ilmu Keperawatan Fakultas Kedokteran Universitas Sam Ratulangi Manado', ejournal Keperawatan (e-Kep).

Restiana, E., Khotimah, S. and Fitrianingrum, I. (2016) 'Uji Aktivitas Antibakteri Ekstrak Etil Asetat Pelepah Pisang Ambon (Musa paradisiaca, Linn) terhadap Propionibacterium acnes PENDAHULUAN Acne suatu proses vulgaris merupakan kronik meningkat pada beberapa tahun Presentase resistensi dan klindamisin, di', 2, pp. 422-433.

Rusmiyati, I., Husain, D. R. and Alam, G. (2012) 'Efek Penurunan Tekanan Darah Ekstrak Etanol Daun Sirsak (Annona muricata L.) pada Tikus Wistar Jantan', 2, p. 8. 